\title{
Outcomes of Antireflux Therapy for the Treatment of Laryngeal Granuloma
}

\author{
Koji Asakura ${ }^{1)}$, Tomo Honma ${ }^{1)}$, Takashi Keira ${ }^{2)}$, \\ Tomonori Nagaya ${ }^{2)}$ and Tetsuo $\mathrm{Himi}^{2)}$
}

The treatment results of 33 cases with laryngeal granuloma (contact granuloma, 31 cases and intubation granuloma, 2 cases) were evaluated. Five of six operated cases with contact granuloma showed post-operative recurrence. Following acid suppression therapy (proton pump inhibitor, H2-blocker, and Rikkunshito) at bed time and nocturnal anti-reflux precautions, 25 of 30 cases with contact granuloma, and both 2 cases with intubation granuloma, showed resolution of their granuloma. The resolution occurred within 6 months in $76 \%$, and within 1 year in $92 \%$ of cases with contact granuloma (between 2 weeks and 144 weeks, mean, 26. 6 weeks).

Keywords : antireflux therapy, laryngeal granuloma, treatment results

\section{References}

1) Shaker R, Milbrath M, Ren J, et al. : Esophagopharyngeal distribution of refluxed gastric acid in patients with reflux laryngitis. Gastroenterology 109: 1575-1582, 1995.

2) Cherry J and Margulies SI : Contact ulcer of the larynx. Laryngoscope 78: 1937-1940, 1968.

3) Wani MK and Woodson GE : Laryngeal contact granuloma. Laryngoscope 109: 1589-1593, 1999.

4）兵頭政光, 田口带紀, 小林丈二, 他：喉頭肉芽腫に対する 治療戦略. 喉頭 16: 102-105, 2004.

5) Nasri S, Sercarz JA, McAlpin T, et al. : Treatment of vocal fold granuloma using botulinum toxin type A. Laryngoscope 105: 585-588, 1995

6) 川崎順久, 福田宏之, 酒向 司, 他: Beclomethasone dipropionate inhaler (Aldecin ${ }^{\circledR}$ ) 吸入療法による喉頭肉芽腫 の治療成績. 日気管食道会報 45: 244-248, 1994.

7）草野元康，下山康之，杉本さやか，他：GERD に対する新 しい問診票 FSS (Frequency Scale for the Symptoms of GERD 通称：F スケール）の開発と評価. 臨と研 82：379382, 2005.

8) Asakura K, Homma T, Okuni T, et al. : Globus pharyngeus and gastroesophageal reflux - a study with frequency scale for symptoms of GERD—. Pract Otol (Kyoto) 100: 485-490, 2007.

9) Hanson DG, Kamel PL and Kahrilas PJ : Outcomes of antireflux therapy for the treament of chronic laryngitis. Ann Otol Rhinol Laryngol 104: 550-555, 1995.

10) Ylitalo R and Lindestad PA : A retrospective study of contact granuloma. Laryngoscope 109: 433-436, 1999.

11）浦野正美, 浅井聖子, 大滝 一, 他 : 特発性喉頭肉芽腫の 臨床的検討. 日気管食道会報 41: 27-31, 1990 .

12) Tsunoda K, Ishimoto S, Suzuki M, et al. : An effective management regimen for laryngeal granuloma caused by gastro-esophageal reflux: combination therapy with suggestions for lifestyle modifications. Acta Otolaryngol 127: 88-92, 2007.

13) Hillel AT, Lin LM, Samlan R, et al. : Inhaled triamcinolone with proton pump inhibitor for treatment of vocal process granuloma: a series of 67 granulomas. Ann Otol Rhinol Laryngol 119: 325-330, 2010.

14) Horiguchi S, Suzuki M, Takagi H, et al. : Clinical course of laryngeal granuloma without surgical treatment. Diagn Ther Endosc 7: 129-133, 2001.
1) Department of Otorhinolaryngology, Muroran City General Hospital

2) Department of Otorhinolaryngology, Sapporo Medical University
Corresponding Author Address : Koji Asakura murohosp012@kujiran.jp 
Effects of antireflux therapy on laryngeal granulomas

\begin{tabular}{ccccccr}
\hline \hline \multirow{2}{*}{ Size of granuloma } & $\mathrm{n}$ & \multicolumn{4}{c}{ medication effect } \\
\cline { 4 - 7 } & & & disappeared & decreased & no changes & rate of diappearance \\
\hline \multirow{2}{*}{ Contact granuloma } & large & 12 & 10 & 0 & 2 & $83.30 \%$ \\
& small & 18 & 15 & 1 & 2 & $83.30 \%$ \\
\cline { 2 - 7 } & subtotal & 30 & 25 & 1 & 4 & $83.30 \%$ \\
\hline Intubation granuloma & large & 2 & 2 & 0 & 4 & $84.40 \%$
\end{tabular}

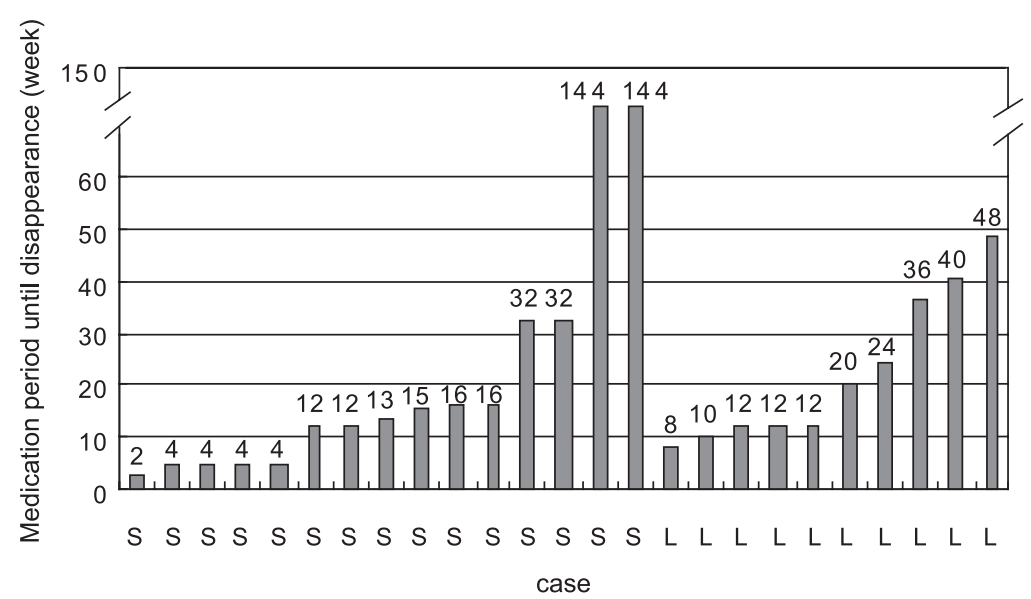

Medication period until disappearance of laryngeal contact granuloma. S: small, L: large 